\title{
BETWEEN THE SA'ALIK AND THE EARLY MUSLIMS: A JAMESONIAN READING ON LAMIYYAT AL-ARAB
}

\author{
Wawan Eko Yulianto \\ Universitas Ma Chung \\ Malang, East Java, Indonesia \\ wawan.eko@machung.ac.id
}

\begin{abstract}
This article aims to propose a possible answer to the curious case of the popularity of Lamiyyat al-Arab as a means of education among Muslim leaders during the Umayyad era. The curiosity lies in the fact that Lamiyyat al-Arab is attributed to alShanfara, who was reportedly a su'luk, an outcast in the society who was also known as a brigand poet. To answer the curiosity, I conducted a literature review on who the $s a^{\prime}$ alik are and how they share some vision with early Muslims. This exploration makes up the first part of the article and the second half is a textual interpretation on Lamiyyat al-Arab guided by the three horizons of interpretation as proposed by Fredric Jameson. Looking at three different horizons of meaning, textual, social, and historical, I strongly hope that the interpretation offer a glimpse into the desire for change that the poem shares with the early Muslims. This constitutes as a possible answer to the curious popularity of the pre-Islamic poem among early Muslims.
\end{abstract}

Keywords: lamiyyat al-arab, sa'alik, early muslims, Jamesonian reading, desire for change

\section{INTRODUCTION}

Umar Ibn al-Khattab, the second successor of Prophet Muhammad, reportedly enjoined the teaching of Lamiyyat al-Arab by the brigand poet al-Shanfara to their children (al-Malouhi in Furani, 2012). The reason is because the poem is an example of the highest morals. In this poem, however, the reader will find, in addition to the morals, narrations about al-Shanfara's raids and killing. This unresolved question has led to a question on how a society built around regimented ethics as the early Muslim society valued such a strong yet problematic poem as Lamiyyat al-Arab. While it might sound simple at a first glance, the answer to this question will potentially lead to a hint on how the early Muslim society viewed poetry and, particularly, the complexity of poetry.

Before venturing further, however, it is important to acknowledge the fact that many literary critics and commentators both from the Arab world and the West have deemed 
Lamiyyat al-Arab a forgery. Some of these scholars support their arguments with proofs that could convincingly make a student of Arabic literature believe that the qasida is indeed a forgery, such as by presenting a report a literary master who claimed to have done the forgery or showing the formal discrepancy between Lamiyyat al-Arab and its contemporaries. However, many others, including those who see early Arabic poetry as oral poetry that was transmitted in the manner similar to what was theorized by Milman Parry and Albert B Lord (1954), see that the poem originates in the pre-Islamic era.

As I will present in this section, Lamiyyat al-Arab's distinctiveness owes to its origin among the $s a^{\prime}$ alik (throughout this article, I use "sa'alik" as the plural form of the term "su'luk"). Suzanne Stetkevych (1993), for example, argues that regardless of the authenticity of Lamiyyat al-Arab as a pre-Islamic poem, we can trace back its attribution to the legendary pre-Islamic figure called al-Shanfara due to its archetypal consistency with the legendary figure. In other words, this poem can as well be a pre-Islamic, although it might not be written by al-Shanfara.

For the purpose of this article, and due to the lack of material evidence on the inauthenticity of Lamiyyat al-Arab, let us suffice to say that Lamiyyat al-Arab is a poem by al-Shanfara from the pre-Islamic period of the Arab Peninsula. Therefore, we can then proceed to the purpose of this article, which is to demonstrate how Lamiyyat al-Arab might share a world view with the early Muslim community and thus indicates the political unconscious of the early Muslim community, a community that was eager to set themselves different from the seventh century Quraish tribe as well as the seventh century Bedouin communities of the Arabian deserts.

\section{THEORETICAL FRAMEWORK}

\section{The Sa'alik and Their Tendencies}

The term sa'alik denotes a social class in the pre-Islamic Arabia that consisted of the poor and the brigands. While the available sources on this term have several major definitions of the sa'alik, they tend not to vary too much. Edward William Lane's An Arabic-English Lexicon defines "su'luk" as both "the needy" and "robber" (1872). In addition to this definition, Lane also includes Urwah ibn al-Ward's attribute as "Urwah al-Sa'alik" as an example; Lane explains that the attribute is caused by Urwah's association with the poor, whom he accepts in his cattle enclosure and feeds them with "the plunder that he took" (1872, p. 1691). In line with Lane's definition that "the poor" and "robbers" seem to intermingle, Alamrani also states that the Sulu'k poet shares the same vision of mingling between life and death, pleasure and grief but Lane lacks the explanation for the correlation between these two seemingly different groups. We can find the correlation between them in A. Arazi's exposition in The Encyclopedia of Islam, where a much longer and more nuanced explanation for the term is available. Arazi carefully defines su'luk from the anthropological and literary perspectives. The sa'alik, according to Arazi, can mean the poor, the robber, or the so-called khali or people disowned by their tribes due to some 
social misconduct that, unless solved by disowning the tribe, will potentially endanger the tribe. It also makes a connection between all these three groups: the strongest among the poor join the rank of the robbers, which is mainly membered by the khalis who, because of their dissociation with their tribes, does not have any way to find sustenance other than to take plunder.

In terms of their active years, the sa'alik were present in the Arabian desert from the pre-Islamic era to the early Islamic era (Arazi, 1997, p. 863; Borg, 1998, p. 670). The absence of a common law code made it difficult to punish a certain misconduct that involved more than one tribe. Therefore, to avoid accepting the consequence of what a member of a tribe did towards another group, the tribe in question disowned the particular member. The advance and rise to power of Islam also brought with it a common law that included injunctions of what to do towards offenders of certain norms. In addition to that, Karen Armstrong in Islam: A Brief History, which is written from mostly Muslim sources, mentions about former brigands who had the chance to be once again members of the community when the inter-ethnic community of Muslims began.

However, that the $s a^{\prime}$ alik were disowned by the society and lived outside, the tribal enclave is not to be interpreted that they no longer had any business with the mainstream pre-Islamic tribal society. On the other hand, there was a recurrent, albeit not good, relationship between the su'luk and the tribal society. As mentioned earlier, even the prominent pre-Islamic poets, Urwah ibn al-Ward, gained his name "Urwah al-sa'alik" because he reportedly provided sustenance to the poor (or the su'luk) of his time while he lived within his tribe (Jones 145). In addition to that, poems by sa'alik poets describe their repeated raids of certain tribes, which is nothing but an instance of their maintained, yet harmful relationship with the tribal community. Asaad al-Saleh argues in his term paper, al-Shanfara still maintains a relationship with his tribe in the sense that he keeps returning to the tribe to define himself. Lastly, one of the theories about the oral-transmission of the pre-Islamic poetry holds that there was a group of rawis or "oral transmitter" who memorized poems by poets from outside their tribes, including the poems of the sa'alik poets (Jones, 2011, p. 21). In other words, the sa'alik needed the society to sustain both themselves and, by extension, their art. This tug-of-war between living away from the tribal society and the need return to it will become be the background for my exploration of the relationship between the world view of the sa'alik and the tribesmen in the social horizon of interpretation which will come in the next section.

As for the poetry of the su'luk, Arazi proposes four "parameters" with which we can appreciate it. The first of these parameters is the apologetic parameter, which sees the poetry as the poet's narration of "his life with particular emphasis on his poverty ... overcome by virtue of his endurance, his courage and determination" (Arazi, 1997, p. 865). Implicit within this apologetic parameter is the poet's desire for the people to understand that $s a^{\prime} a l i k$ 's offenses are necessary for their survival. The second is the lyrical parameter, which puts emphasis on the poetry's tendency to endow sentimentality through the portrayal of the natural settings-both the topography, the fauna, and their tools to 
survive-where the $s a^{\prime}$ alik spend their time while being away from the tribe. The last parameter is what Arazi calls the "therapeutic parameter," which views the poems' depiction of how the sa'alik lived a harsh life a certain awareness of the looming danger in their life. This parameter helps us see the sa'alik as people who were aware of death but not as a scary thing and were brave to express their critique to the tribal community that they left.

Lamiyyat al-Arab is indeed pregnant with examples of these four parameters to the degree that we can call it a su'luk poem in the strongest possible term. Although it begins with a staunch statement of al-Shanfara's rejection of the tribal life, which ranks high on the therapeutic parameter, the poem also demonstrates many other qualities that check off the other two parameters. The simile of wolf that al-Shanfara uses to describe his traveling life, which Alan Jones values tremendously, is an element that scores high in the sentimental parameter. Arazi's statement about the idealization of weapon as an instance of the sentimental parameter seems to owe a lot from al-Shanfara's use of the image of a great, yellow, long-necked bow that he keeps as a companion to sustain his life. The elements of the poem that can fall within this sentimental parameter seem to be very strong, to degree that al-Shanfara uses the image of a harsh mountain terrain that, prior to his arrival, has only been accessible by ibexes. The descriptions of the pang of hunger and the moral virtues that underlie al-Shanfara's decision to live the harsh life away from the tribe, hunted by the death, score high in Arazi's apologetic parameter. Again, it seems rather vivid that this parameter is built upon the assumption that Lamiyyat al-Arab is a su'luk poem par excellence.

One last thing that we need to keep in mind with regards to the distinct quality of the su'luk poetry will surface when we juxtapose them to the mainstream pre-Islamic qasida. By more mainstream qasida here I am referring to works attributed to other poets and those that talk about the tribal or desert life that moves from one source of water to anotherhere I will mostly count on the Muallaqat poem to represent the mainstram pre-Islamic poetry. Ibn Qutayba, in a frequently quoted passage mentions the traditional sections in the pre-Islamic qasida, namely the atlal (the lamentation over the beloved deserted encampment), nasib (or the erotic prelude), rihla (which contains the narrative about the persona's journeys), and madih (or the panegyric) (Irwin, 2002, p. 5). While to some Western readers are prone to consider the qasida lacking the formal unity due to this manner of division (Irwin, 2002, p. 4), today's critics see that there is an organic unity among these elements. In his extensive structuralist study of the structure and meanings of Muallaqa of Imru al-Qays in, Adnan Haydar states upfront that the qasida is the manifestation of the "vision" of the pre-Islamic Arabia (1977, p. 227); Haydar's structural analysis reveals an organic unity in the poem whose parts at the surface look unrelated to one another or have hitherto always been considered proper names that only function to refer to certain places without any inherent content. Somewhat on the same wavelength about the presence of the organic unity in the qasida is Suzanne Stetkevych's argument that the structure of the pre-Islamic qasida suggests its ritualistic importance due to its 
similarity with the idea of the rite of passage (1993, p. 6). The seemingly disjointed elements of the pre-Islamic qasida have its intricate way to achieve an organic unity. The su'luk qasida and su'luk poetry in general, nevertheless, do not share the same manner in achieving its organic unity.

The Su'luk poetry has a different structure and contents that are easily distinguishable from the mainstream pre-Islamic qasida. While most pre-Islamic qasidas begin with a section traditionally known as the atlal (deserted encampment) which is then followed by the nasib, a su'luk poetry does not. In his introduction to al-Shanfara, Robert Irwin on the absence of nasib in su'luk poetry by stating that "The sa'alik poets had little time for sentiment and nostalgic yearnings" and that "Shanfara is a poet as thug" (19), a statement which I will prove to be too simplistic. Furthermore, Irwin also comments on the fact that Lamiyyat al-Arab in particular lacks the trappings of the qasida and suspects that this is what gives the poem an unusual thematic unity as a pre-Islamic qasida. Meanwhile, for Suzanne Stetkevych, under the assumption that the pre-Islamic poetry has a strictly ritual nature which demands a poem to have certain building blocks, the absence of some elements in Lamiyyat al-Arab makes it what she terms "a failed or aborted rite of passage, in which the passenger/poet remains perpetually in the 'liminal' antisocial phase that corresponds to the rahil section of the qasida" (Stetkevych, 1993, p. xiii). While I do not completely agree on seeing Lamiyyat al-Arab necessarily in ritualistic term which implies that Lamiyyat al-Arab and other su'luk poems of lesser importance compared to the other pre-Islamic qasida, Stetkevych's critique highlights the starkly distinctive nature of the su'luk poetry among its contemporaries.

Having presented the various views about the su'luk and the distinctiveness of the su'luk poetry, it is worth noting that one of the problems that scholars of pre-Islamic Arabic literature are critical about is the lack of authentic pre-Islamic source about the poets themselves. Most of the available sources on the pre-Islamic Arabic literature and civilization are from the early Muslim era, namely the late Umayyad and early Abassid eras. Stetkevych, in her chapter on Lamiyyat al-Arab entitled "Archetype and Attribution: Al-Shanfara and the Lamiyyat al-Arab," departs from the fact that there have been a lot of debates regarding the authenticity of Lamiyyat al-Arab and its authorship by the legendary su'luk al-Shanfara. In the article, instead of contributing yet another argument for or against the authenticity of al-Shanfara, she explores the possible reasons behind the attribution of the poem to al-Shanfara. Stetkevych (1993, p. 131) reveals that this attribution is made possible by the archetypal matches between what al-Shanfara the persona experiences in the poem and the legendary al-Shanfara as he is described in a seemingly contradictory manners in a number of akhbar, narrative accounts from the early Islamic era which are mostly based on oral history. This is the assumption that I also adhere throughout this article.

This is where the connection between Lamiyyat al-Arab and the world vision of the early Muslim becomes tangible. In her study of al-Shanfara, Stetkevych brings up Goldziher's view with regards to the worth of the compilations of the prophetic 
Traditions, or hadith. Goldziher argues that "The hadith will serve not as a document for the history of the infancy of Islam, but rather as a reflection of the tendencies which appeared in the community during the maturer stages of its development" (in Stetkevych, 1993, p. 124). It is worth mentioning here that while this critical scholarly attitude behind Goldziher's view can pass for a blasphemy for the majority of today's Muslims, it is still important to keep this in view mind as today's Muslims debate over a number of hadiths that some groups devoutly follow while the progressive section of the Muslim community considers need re-contextualization. I consider Goldziher's argument important for the study of the pre-Islamic Arabic poetry because the pre-Islamic oral poems were first anthologized approximately during the same time as the compilation of the hadiths. This awareness can shed a light on poetry itself, especially Lamiyyat al-Arab, which, as I mentioned in the opening of this article, is said to have been recommended by Prophet Muhammad, or Umar ibn al-Khattab, who is the second caliph that succeeded Muhammad and-as an additional information - was said to be an "expert in Arabian poetry" and had converted into Islam after hearing the beauty of the Qur' an recited by his sister (Armstrong, 2007, p. 5).

Whether or not Lamiyat al-Arab was really enjoined by the Prophet or Umar ibn alKhattab, the oral story that the poem was taught to the Abassid princes also suggests its valuation by the early Muslims. What I consider really important in understanding the relationship between Lamiyyat al-Arab and the early Muslims is the relationship between the su'luk and his tribe or the tribal society in general which is marked with high contrast in terms of social class.

There are at least two types of relationships between the su'luk and the tribal community. Some sa'alik live in the tribal society and depended on the mercy of more fortunate members of the tribe, as Urwah ibn al-Ward describes (with contempt) in his poem Man Huwa al-Su'luk?This particular group of $s a^{\prime} a l i k$ lived at the bottom of the food chain and had nothing in the way of dignity. The second group, however, consisted of those who were determined to leave the tribe and to create a community of brigands. This is the group that have decided to live outside the enclave of the tribe and to be brigands such as the one narrated in Lamiyyat al-Arab, that is a person who decides to leave his society instead of living as a poor man who receives the mercy of its richer people. For alShanfara in the poem, it is better to live needy instead of receiving help that will eventually only degrade himself. This second group, for whom Lamiyyat al-Arab can be read as a manifesto of some sort, was the one that, I argue, shared with the early Muslim society the common unconscious impulse for freedom from their undesirable roots.

Among the early Muslims, there appeared to be a tendency to create a distance between them and the Bedouin society. In his research on the concurrence of the development of Islam and the rise of the Arab polity, Suliman Bashear begins by discussing what he sees as the demeaning tendency towards the Bedouin, which is known as the $a^{\prime} r a b$, in the Qur'an as well as in hadith $\left(1997\right.$, p. 10). The term $a^{\prime} r a b$ here shares a lot of similarity to the idea of the tribal pre-Islamic mainstream society. Bashear's analysis 
seems to be built upon Goldziher's view of the worthiness of hadith collection as collection of documents which, as I quoted earlier, "reflects the tendencies which appeared in the [Muslim] community during the maturer stages of its development." This attitude, as Bashear interprets it, highlights the superiority of the umma over the Bedouin's tribal community.

There are at least two ideas that are vital in relation to this concept of the umma, namely the migration and the disappearance of the ethnic sentiment. In many occasions, the term umma is commonly limited to refer to the society of the believers, especially those who migrated with the Prophet Muhammad from Mecca (Bashīr, 1997, p. 14). If this is not enough to indicate the desire of the early Muslims to break away from their undesirable polytheistic, another significance of the migration might give a better view of its utmost significance among the early Muslims. Later on, according to the oral history of the early Muslims, Umar ibn al-Khattab decided the year of the migration as the first year in the Islamic calendar. Everything that happens with the Islamic civilization since that migration will be marked by the number of years that span between the Migration that particular event. In other words, the history of Islamic civilization begins in the year Muhammad left his hometown in Mecca. These two instances hint at the importance of the migration or departure to signify the point of separation between the polytheistic ways and the Islamic ways.

The second important tendency that we can draw from Suliman Bashear's interpretation of the hadith related to the Bedouins is the inclusivistic tendency (1997, p. 15). By inclusivistic tendency, I am here referring to the tendency to not merit individuals based on their ethnicity but on the common belief in the new religion preached by Muhammad. Bashear finds this in hadiths that state for example the superiority of the members of the Muslim ummah over the $a^{\prime} r a b$ from Mecca even if the former was originally from Persia or Abyssinia. This attitude is apparent even in ritual contexts in which there is a tradition that "mentions bedouins among those who are not allowed to lead in prayer or even to be in the first row [respectable position] during prayer" (Bashīr, 1997, p. 12). While it is easy to misconstrue these Traditions as the tendencies among the early Muslims to discriminate only the Bedouin, Bashear also presents his finding that the basis of this attitude is the fact that the Bedouins were not Muslims; some hadith also mentions that this attitude can be different as long as the persons in question were believers. In the perspective of the early Muslims, the desert people had "uncouth" characteristics such as unbelief, hypocrisy, and covert sensuality (Bashīr, 1997, p. 13). What we can take from this analysis is that the early Muslims needed to distinguish themselves from who they were not. Their new society was no longer defined along the ethnic lines but along somewhat ideological lines. To do that, a series of attempt to leave the old order and to embrace the newer order was necessary.

As a conclusion to this section, there was a similar pattern in the attitudes of the early Muslims and the $s a^{\prime} a l i k$ towards their group of origin. The $s a^{\prime} a l i k$, at least those who were considerably determinant, left their tribes in order to live in the mountains as brigands. 
They left their groups and all the things that they considered bad. As for the early Muslims, their migration to Mecca and their tendency to include people of other ethnicities as their member were the basic elements for the formation of the umma, which dismantled the previous tribal mode of living.

\section{The Desire for Change}

At the outset, Lamiyyat al-Arab appears like a narrative poem about a man who leaves the comfort of his tribe in favor of a harsh life in the desert and mountains. Deeper still, we will find a character who champions a non-conformist life. Even though he has to live a lonely difficult life, he feels more peace of mind because he can avoid experiencing the worst of the society and can maintain a high standard of ethic. A positivist reading of the poem might result in the confirmation of high moral standards that might partially explain the reason why the early Muslims considered this poem important. However, such positivist reading might leave us with an unexplainable question why the poem was still held with respect among the early Muslims even though al-Shanfara in this poem is a person who robs and kills people with pride. In exchange for such approach, I am here offering to read the poem on several layers of interpretation to unearth the conscious as well as the unconscious significations with the hope to shed light on the social context where the poem has originated and the audience where the poem was held with respect. In this section, I argue that the popularity of the poem among the early Muslims, and its subsequent inclusion into the hadith regardless of its lack of authenticity, is associated with the poem's political unconscious that coincided with the world vision of the early Muslims.

\section{METHOD}

Fredric Jameson argues in The Political Unconscious that a literary work, as a cultural artifact created by an individual whose consciousness is shaped by his historical and social context, has what he terms "the political unconscious." This political unconscious is what relates the literary work to its social context and to the desires of its members. Since the creation of a cultural artifact involves conscious process and conscious decision making, such as to create the fictional depiction, any positivistic attempts to interpret a one-on-one signification will fall short. At best, such approach can only be effective to read works that are explicitly allegories. The effective move, thus Jameson argues, is when a critique unearths the political unconscious through the three layers of interpretation which consider what we traditionally understand as the "intrinsic" as well as "extrinsic" factors of a literary work. Eventually, the combination of all these factors will render irrelevant the separation between the intrinsic as well as extrinsic aspects or the form and contents of a cultural artifact. These three horizons are the political, social and historical horizons.

In the political horizon, I read Lamiyyat al-Arab, mostly through an explication $d u$ text of some sort. However, as opposed to the common explication $d u$ text that interprets a literary expression to come to arrive at hidden meaning behind the expression, my 
reading, following the example set by Jameson, interprets the literary expression as a symbolic solution to or a wish fulfillment for the contradiction (resolved or unresolved) that is present in the author's world (Jameson 61). In the second or social horizon, I scrutinize Lamiyyat al-Arab for the elements of the poet's ideology, reading the work as an utterance by a member of a certain social category. In other words, I treat Lamiyyat al-Arab as a voice on behalf the social group known as the su'luk. Jameson calls these utterances that reflect a particular ideology "ideologemes." Lastly, in the historical horizon, I analyze Lamiyyat al-Arab as a literary work that carries in it the style or genres of literary works that came before it or that exists outside its social context; to complement that, I will also analyze what each of these elements carries and how these elements interact with each other.

\section{DISCUSSION}

In the first horizon of interpretation, Lamiyyat al-Arab presents the persona-who identifies himself as al-Shanfara-who makes a strong statement about his decision to leave the tribe. Before going further, however, it is worth mentioning that I am of the opinion that the persona al-Shanfara should not be confused with the legendary su'luk asShanfara due to the mostly literary-as opposed to historical-nature of Kitab al-Aghani and the akhbars from which most of what we know about al-Shanfara comes. Al-Shanfara's decision appears to be a solution for a number of things that he could never solve other than by leaving the tribe altogether. In this respect, Lamiyyat al-Arab is a symbolic solution to a problem that poor members of a tribe during the pre-Islamic Arabia could not solve in the real life. There are several reasons that we can explore to see the political unconscious that is hinted at this horizon of interpretation.

The first of these is related to al-Shanfara's decision to leave the tribe due to his grievances against his tribe. These grievances include the tribemen's tendency to make public something that a person considers a secret, the greediness among the member and the demeaning behavior of those who help others in the tribe. In the first section, after telling his tribesmen to leave him, he declares that he has three friends-the wolf, the panther and the hyena-who show the quality of a real folk:

They are the [real] folk: they do not spread abroad any secret entrusted to them, nor do they desert anyone because of what he has done. (line 6) ${ }^{1}$

The fact that this comes up before anything else indicates al-Shanfara's emphasis on the inter-personal relationship in a tribal life. For him, keeping a secret that one is entrusted with is of the highest importance. This particular grievance does not seem to be restricted to the relationship between the poor members of a tribe with the other members. This sounds more like a critique to the general tendency of the tribal life. In addition to that, his statement about a (real) folk not "[deserting] anyone because of what he has

1 The translation of Lamiyyat al-Arab used throughout this article is by Alan Jones. 
done" can be read that tribal comradeship should have been very deep to the degree that a tribesman should understand the mistake that a fellow tribesman has done, as opposed to deserting the person who has made a mistake. We are here reminded of Arazi's definition of the su'luk in which the lack of law enforcement made it necessary to disown a member of a tribe when he does something that the tribe considers harmful to the entire community. Here, al-Shanfara expects his tribe to not just disown its member for what he has done. By extension, al-Shanfara here is a person who considers kinship worthy to be maintained, a view that apparently he does not share with his society, which favors the well-being of the tribe instead of saving the kinship.

Al-Shanfara presents another practice in his tribe that he despises: the rapacity of his tribesmen. In the beginning of the second section, al-Shanfara tells about his tribesmen's greediness when food is available, although in reality he claims that he has put more work than the other tribe members in securing that food (lines 7 -9). Further on in the poem, this time in the mountain, al-Shanfara depicts an incident in the wild that is the opposite of the despicable tribal practice:

The dusty sand-grouse drink my leavings after the have journeyed abroad at night to water, with their sides reverberating [as they fly];

I did my utmost and they did their utmost; we raced with each other; they beat their wings and I tucked up my izar; and I got to the water first, though I was taking things easily.

They swallow down a hasty drink, and then move off quickly with the dawn, as though they were a party of travellers making haste from Uhaza in the early morning. (lines 37, 38 and 41)

In addition to al-Shanfara's boasting that he is still superior to the birds eventhough he does not put much effort, these lines are also pregnant with the good spirit of competition in the company of the wildlife: al-Shanfara would race for the privilege to quench his thirst before others. Al-Shanfara races to get the water before the birds, and when he gets there he enjoys that water. So are the sand-grouse, they take just as much as they need it and "move off quickly with the dawn," as opposed to what he describes about his tribesmen:

\section{If hands are stretched out to food, [mine are] not the swiftest of them, for the greediest of} the tribe are the swiftest.

That is simply a generous act [on my part], for I am superior to them: and the most superior of men [constantly] has to strive to keep a surplus available. (lines 8 and 9)

This comparison indicates how al-Shanfara views the tribal life where some people have to work hard without really enjoying the fruit of his hard work because there are greedy members of the tribe who will race to enjoy this good before even the most rightful bread winning members. It seems from this part that al-Shanfara has all the reason to leave his tribe. 
As a consequence of this defective tribal life, al-Shanfara prefers to stay away and to find his own community, which as he says early on in the poem consists of the wolf, the panther and the hyena (line 5). Of course, these three animals are only a metonymy for the entire wildlife; and he definitely picks the fiercest of all the desert beasts, which actually also include the ibexes and sand-grouse that he also depicts further into the poem. The fact that he finds comfort in these wild animals, which are not at all his kind, is a statement in itself: for a person who is rejected by his own flesh and blood, a society that he can associate with does not have to be of his own kind as long as they could understand him. Therefore, al-Shanfara finds it necessary to declare upfront:

I have folk [to keep me company] without you: swift wolf; sleek, spotted [panther]; and shaggy-maned, loping [hyena]. (line 5)

For sure, this is a bold statement of al-Shanfara's view of an ideal community: to live ethically even if he is among members who are different from him is still more desirable than to live with despicable people even though they are his own kin - or, in al-Shanfara's idiom, "the sons of my mother."

The second reason for al-Shanfara's decision to leave the tribe is related to dignity or upholding his own morals. To him, dignity is of utmost importance to the degree that he would preserve it at the expense of convenience. This is all summed up in the following lines:

I prolong putting off [the satisfaction] of my hunger until I make it die, and I turn aside thought from it and neglect it,

And I would lick up the dry dust of the earth rather than [allow] any boastful man to think that I owe him any generosity.

And were it not for the avoidance of blame, there would be no item of drink or food, by which life is sustained that I would not have had. (lines 21-23)

These lines have made it explicit the reason of al-Shanfara's departure from the tribe, including what he considers important. These lines come after al-Shanfara's statement of the idle individuals in the tribe, from whom he distinguishes himself. Furthermore, AlShanfara, according to Mansour, also distinguishes clearly between two social entities, ahl (kinsmen) and ashab (companions and friends. Following Alan Jones, who considers it more productive to take works by other sa'alik poets as a source of comparison instead of using sources like Kitab al-Aghani, I believe to be more productive in this occasion to turn to Urwah ibn al-Ward's poem Man Huwa al-Su'luk? for an explanation. This poem has a persona who justifies the raids and thieving that he does (i.e. his being a su'luk) as one way to sustain the lives of the needy around him. In a section of this short poem, the persona describes a type of su'luk whom he views with contempt because of their lack of dignity and full of idleness:

May God cover with shame a su'luk who, when night falls for him, is one who rummages about for odd pieces of bone, while he frequents every place where a camel has been slaughtered.

He reckons as good fortune from his fate every night in which he meets with 


\section{hospitality from a friend who has resources. (lines 13 and 14)}

Al-Shanfara, in favor of his dignity, is willing to leave the enclosure of his tribe for the desolate wasteland, even if it brings him more physical suffering. For al-Shanfara, instead of being demeaned because of being idle, he would rather "prolong putting off [the satisfaction] of my hunger until I make it die" (line 21) or "lick up the dust of the earth" (line 22) or sleep on the "fleshless vertebrae showing through my arched back" (line 42). This miserable condition gives him all the peace of mind that otherwise he would never feel if he still lived in his tribe and received help only to be demeaned. His decision to leave is unwavering even though he knows that up ahead he would be suffering.

The last aspect, which must have charmed the early Muslims or anyone who values ethics for that matter, is the optimistic attitude towards reality, somewhat resembling what Jameson would call a utopian impulse in the face of a hopeless life. The free life away from the tribe that he longs for can lead to ugly ends, such as the hunger, the severe weather, as well as the danger of retaliation from his enemies. This negative situation, however, does not even a bit stop al-Shanfara from leaving his biological folk. In the face of these tribulations, he even shows a positive attitude about the future, such as when he says "At times I am destitute, at others rich, and wealth is attained only by him who wanders far and exposes himself to risks" (line 51). There is an air of optimism in the way he sees his venture. On top of that, al-Shanfara even boasts of his topnotch patience, a mental capacity that is highly-valued among the Muslims society. This quality is considered one of the most important moral teachings that one can gain from al-Shanfara. For the Muslims, the capability of enduring hunger and hardship is valued highly to the degree that the Qur'an mentions it several time. Complementary to this attitude is alShanfara's statement that he will not be "boastful, putting on airs under [the influence of] wealth" (line 52). Like the previous reasons of departure that I have presented above, this departure from the tribe apparently brings about good things. The hardships that comes from hunger, weather, and danger are eclipsed by the value of the unwavering moral stance. This is once again a proof that the departure from the tribe, despite the difficulties that it carries, includes in it an answer-and a much needed one-to a problem that alShanfara is currently having with his tribe.

These three points, i.e. his grudges against his tribe, his desire to preserve dignity and his positive attitude in the face of tribulations, all lead to the view that there is a problem with his tribe and departure from it is the only viable solution to this problem. As for the common moral values that al-Shanfara shares with the Muslim in this poem, these are good explicit teachings that one can pick from the work. However, these morals are not at all uniquely Islamic as they are universal and we can expect to find them in most religions or belief systems that were common in the pre-Islamic era. Let me repeat again here that what I argue to be more related to the Muslim is the political unconscious behind this story, that is, the departure from a tribe to solve the disgraceful condition experienced by the poor or the wrong-doers in the tribal community. This will be even clearer in the succeeding horizons of interpretations. 
If on the political horizon we see the poem as a symbolic representation for the poet's grievances about his society and the necessary solution to this problem, the interpretation on the social horizon will take these personal grievances to a higher level, that is, the social class to which the poet belongs. This means that we see Lamiyyat al-Arab as an expression of the entire class of the $s a^{\prime} a l i k$. This is done by focusing on the elements of the poem that are the main building blocks in the consciousness of $s a^{\prime} a l i k$. In practice, I will focus on setting and metaphors as categories instead of analyzing the meaning of individual metaphors and spatial setting. For that purpose, I will focus on the spatial setting and the beasts in this poem. At the end of the discussion in this interpretive horizon, I will conclude that there is an irreparable rupture between the su'luk and the tribal society.

In Lamiyyat al-Arab, the fact that there are two modes of settlement, i.e. tribal settlement and desert/mountain, tells a lot about the social condition that marks the boundaries of the poet's imagination. In short, these places are the only places that the poet could conjure up in his work if he is to be considered a reasonable poet-a pre-Islamic Arab man like al-Shanfara cannot reasonably write a poem set in the urban settlement with narrow alleys such as in Rome. In Lamiyyat al-Arab, the poet could have come up with any place that has its own symbolic relevance; these places, however, still fall within the realm that is not alien to the poet, which also tells about the range of the author's consciousness. The boundaries of the poet's imagination are the encampment and the desert/mountain - for lack of a better term, "desert/mountain" is used to indicate any geographical locations in Lamiyyat al-Arab other than the tribal encampment. Quite expectedly, these two geographical locations are juxtaposed in such a way that reflects their opposing and contradictory nature.

The opposition between the desert/mountain and the encampment in Lamiyyat al-Arab is apparent from the fact that twice as much emphasis is put on the desert/mountain. The poem indeed starts in the encampment, and for the first twenty-five lines it talks about the ills of the tribal life. For the remaining two thirds of the poem, the reader can only see the persona's presentation of the life in the desert/mountain. The only moment al-Shanfara returns to the tribe is when he goes to a tribe and kills the men or does the robbery. A solitary life in the desert/mountain is not the kind that anyone would enjoy living, but for the persona this hardship is worthwhile. In fact, we can see the desert/mountain part of the poem as a justification - through its hardships and freedom - of how big of a struggle al-Shanfara has to make and how freedom he could gain as the consequences of leaving his tribe. In short, the last two thirds of the poem is the answer to the first third.

For the su'luk, both the needy and the robbers, life in the tribal encampment is marked with difficulties with regards to their relationship with the other members of the tribe. In this case, Lamiyyat al-Arab is just an instance of this su'luk experience in the tribal encampment. Another example of this tendency is found in the works of other sa'alik poets such as Ta'abbata Sharra and Urwah ibn al-Ward. For Urwah ibn al-Ward, even though his major poems including Man huwa l-suluk? center around his life as a su'luk in a tribal community, they show the idealization of raids and travels in the mountains. In Man huwa 
l-suluk? he even justifies the raids that he does as a means that enables him to help the needy in his tribe. He says to Umm Hussan, who has rebuked him for raiding and lying in ambush as if he is not satisfied with the wealth that he already has:

The people who resort to you [Umm Hussan] - I mean those related by blood, and all those women, black of wrist, who come to you, prevent my staying at rest.

And those who ask for help, whose father is Zayd -I see no way of turning them away. So hold fast to your respect and endure the situation. (lines 11 and 12)

Urwah ibn al-Ward in this poem is a person who empathizes with the su'luk, unlike other members of the society. The manifestation of this empathy, however, includes the raid of other tribes. Even though the words "mountain" and "desert" is not present in these two lines, the statement can only refer to the travel across the deserts and mountains to do the robberies and raids. He does all this for the sake of putting his heart at rest. From here, we can say that Urwah ibn al-Ward, unlike Al-Shanfara who has physically left the tribal settlement, is still physically present within the tribe while by ideology is a su'luk who celebrates the life in its primal state. Also, for Urwah ibn al-Ward, these ventures are for the sake of helping the needy who otherwise will not get sustenance.

However, despite the predominantly desert/mountain setting and the idealization of life in this setting, we can by no means rule out the relative significance of the tribal life for the su'luk. This is also apparent in Lamiyyat al-Arab. The act of proposing the harshness of life away from the tribe itself is the reminiscence of the poet's acknowledgment of the meaning of the tribal life that he rejects. However, this acknowledgment is not a tangible one. What is tangible is the recurrent tendency to present the mountain life in a way that would be sensible to those who live in the tribal enclosure. This shows up in Al-Shanfara's predilection to use tribe-centric idioms to conjure up the elements of desert/mountain other than himself-for himself, who can be present in person in the tribe, he uses the natural element, such as the wolf.

In the part where he talks about his means of survival, i.e. "the dauntless heart, a bright, sharp [sword] and a yellow, long-necked [bow]" (line 11), al-Shanfara uses a mother bereft of his son to personify the painful-sounding twang as the arrow glides away from the bow. Al-Shanfara says:

When the arrow glides from it, it moans, as though it were a woman, smitten and bereft of her child, screeching and howling. (line 13)

This painful-sounding twang would forever belong to the realm of the su'luk-i.e. would never be grasped by his tribal audience-if it were not for the tribal-centric personification. The next occasion this technique resurfaces again is in the wolf simile, a section that has won al-Shanfara praises from the Western critiques (JONES). The wolf, an image that he conjures up as a simile for his famished self-roaming the merciless desert, is so unimaginably thin that al-Shanfara has to use the image of "arrow shafts being shaken in the palms of the maysir dealer" (line 29). Thus, we have the case of double simile in which a simile needs to be made more sensible through the use of another simile, which is closer to the imagination of the audience. He presents the dice of the gambler as the 
simile for this metaphoric wolf - which, as I indicated earlier, functions to present himself in the wild.

The last of this type of metaphor can be found in the final part of the poem when he is atop a mountain that is usually accessible only by ibexes. Here, in his peace of mind, alShanfara says "The dusky-brown ibexes roam about around me, looking like virgins wearing garments with long trailing trains" (line 67). The ibexes are elegant in their moves and agility, but they have to be introduced to his audience through the image of virgins who without a doubt are supposed to be members of a tribe instead of members of the sa'alik.

Through the tribal-centric images that are taken from his tribal life and how these images function within the poems to personify the mountain life, we can see a portrait of two social classes in the pre-Islamic Arabia: those who live a solitary life in the wild and those who are in the "civilization" or the tribe. One of the classes is found in the nomadic tribal settlements; the other lives in the mountain areas and roaming around the desert and raid one tribe after another. Al-Shanfara's account points out the despicable aspects of the tribal life while at the same time highlighting the virtues of the life that the su'luk lives. What is undeniable is the fact that to sustain his life the su'luk needs to return over and over to tribal settlements to raid them. This is analogous to how al-Shanfara has to resort to idioms from the tribal life if he is to make his depictions of the mountain life achieve their effects. This dynamics hint at the problematic relationship between the poet and its audience, which is central to the discussion on the historical horizon of Lamiyyat al-Arab.

Finally, the political and social interpretations of the poem bring us to the historical reading of Lamiyyat al-Arab. After 1) seeing the departure of the su'luk from his tribe of origin as a symbolization of how one solves a problem with his/her tribe in the pre-Islamic society and 2) exploring how the dynamics of the desert/mountain and tribal settlement in the poem is an instance of the way the su'luk idealizes the desert with the freedom that it offers, we are now ready to see the further implication of Lamiyyat al-Arab as a poem that has in it important aspects of history through its use of two different genres. Since each genre has its own background, which is tightly related to the mode of production in the social context of the work in question, the use of a particular genre brings with it the social context and history of that genre. Therefore, the genre of qasidah and the modification that the poet does to it helps us understand another layer of the political unconscious in Lamiyyat al-Arab. It is through the dynamics of these two styles that we can see the readiness of the community to change to a new mode of living.

In his commentary of Lamiyyat al-Arab, Alan Jones brings up a past debate among the scholars of pre-Islamic Arabic literature about the genre of this poem in which the commentators argue whether or not it is a qasida. Those who argue that Lamiyyat al-Arab is not a qasida usually point out the fact that Lamiyyat al-Arab does not have the conventional atlal and nasib scene. The other side of the debate usually disproves this argument by either showing the fact that the formulation of qasidah was made by later 
critiques and it does not make sense to do back-projection and "require" all pre-Islamic poems to follow the formula (Jones 159). Others counter that argument by saying that the su'luk is not the sentimental type who would lament on a deserted encampment or narrate past erotic encounters (Irwin 15). The atlal scene itself is strongly related to the tribal life, because it represents the sentimentality of one who looks at a past settlement-in compliance with the fact that the desert people move from one source of water to another to find where the rain has fallen (Arberry 5). The su'luk, however, especially those who have decided to leave the tribe, does not have anything to do with the deserted encampment or an erotic description of his life with the women of the tribe. Not only does he have no time for sentimentality as Irwin comments on in passing, he has rejected the idea of living with a group or moving from one place to another with them. Therefore, the idea of lamentation over a deserted camp such as the one done by the poets of the Muallaqat is irrelevant to him. What we can gain from this debate is that Lamiyyat al-Arab is a qasida that also has aspects that are common in pre-Islamic qasida; however, the fact that it systematically eschews the fundamental elements that are common in other qasidas renders it a different type of qasidah.

Related to Lamiyyat al-Arab's being a qasida of a different type, the relationship between the poet and his audience is also different. The frequently quoted passage from Ibn Qutayba shows the relationship between the conventional thematic units serves to cater the oral recitation of poem. Ibn Qutayba argues that the poet makes its claim in a qasidah only on the third thematic unit, after he is convinced that he has won his audience's attention by presenting enchanting atlal and nasib (Arberry, 2018, p. 15). If this is correct, then al-Shanfara has discarded two important elements that have been used by his contemporaries or predecessors. He presents, instead, the opposite of the typical atlal scene: al-Shanfara tells his tribesmen to hurry and leave him in the desert/mountain to be with the new folk. Instead of presenting erotic encounter(s) after the opening lines, alShanfara tells of how his tribesmen have shown greediness, and given him not the first share of the plunder, although in fact he has been the most industrious member of the tribe. In contrast to J.T. Monroe's theory on the tendency of oral poets to use "a fixed traditional repertory of themes" that he "may alter, lengthen, shorten, transpose, or omit theme in response to the audience's interest" (2017, p. 43), al-Shanfara is unhesitating in presenting his agenda and making his case. He is not concerned about retaining his audience by using literary elements that can "entertain" them. This brings us to the question audienceship of Lamiyyat al-Arab.

Lamiyyat al-Arab is a poem that communicates to its audience in a way different than other qasidas in its era. In fact, Lamiyyat al-Arab addresses not an audience that is gathered together to enjoy a poetry recitation as, according to the traditional accounts, was common in the pre-Islamic era. Neither is it a poem by the spokesperson of a tribe whose duty it is, as an eleventh century Arabic literary critique puts it, to defend the tribe's honor and to protect their reputation (Arberry, 2018, p. 14). Lamiyyat al-Arab is unlike the Muallaqa by Imr al-Qays in which the poet/persona addresses an enchanted audience and presents a 
poem that evokes his nostalgia with past lovers, erotic ventures and encounter with the ideal woman that has captivated his heart, his rise from the nadir of his life and the return to order of his life and his world. Lamiyyat al-Arab is also different from the qasida of Amr ibn Kulthum which is a defense for his people against the king who has disgraced the honor of his mother and his people-which in turn is an attempt to rouse his morale and that of his people. Lamiyyat al-Arab is a statement made by a poet/persona to his audience. It is explicitly addressed to the audience who has wronged him collectively. It presents, as I discussed earlier in the interpretation of the social horizon, a manifesto that enumerates his reasons for leaving them and his exposition of the fact that his departure from them has led to freedom and dignity - although it is accompanied by sufferings, which he does not mind to endure.

Lamiyyat al-Arab is more like a statement than a description. According to Adnan Haydar, the paradigmatic distinctions between the pre-Islamic era and the era after the advance of Islam include the way each paradigm sees the connection between the text and the world (Lecture note). The pre-Islamic poet works under the assumption that the truth precedes the text, which translates into the common practice of composing a poem that describes a past happening. The ramification of this paradigm is the relativistic nature of the poetry. As for the Islamic era, there is a basic assumption of that the world comes after the text. In practice, the Islamic poetry or text in general carries a particular message or meaning that in turn will have to be carried out. It works under the positivistic assumption instead of the relativistic assumption. Lamiyyat al-Arab, if we see it as a statement to alShanfara's tribe, carries a strong message about or an argument for his tribe that he has decided to leave the tribe for the said reasons and his audience cannot do anything other than understanding the reason and acknowledging that his decision is justifiable. Therefore, Lamiyyat al-Arab anticipates the coming of the next mode of creative production.

\section{CONCLUSION}

Lamiyyat al-Arab shows a major difference from other pre-Islamic qasidas. Not only does it have different building blocks than the ones found in its contemporaries, it is even built upon a totally different assumption. Instead of being a work composed by a person who had no time for sentimentality, which was desired by the audience, Lamiyyat al-Arab is a poem composed by a poet who desired to make a statement because he had been wronged by this audience. On top of that, this poet was at the highest of his emotion to part ways with the society that he could no longer tolerate. This is in line with the spirit of the early Muslims who tended to set the distinction between themselves and the Bedouin society. From this exposition, we can say that al-Shanfara finally found the "other folk" than his own tribe, and this folk came a century or so after him: the early Muslims. 


\section{REFERENCES}

Alamrani, Gamil. (2015). Sulu'k Poets in a Post-Modern Perspective: A Study of AlShanfara's Lamiyyat Al-Arab Based on Nietzsche's Philosophy of the Aesthetics. International Journal of Language and Literature. Vol. 3, No. 1, pp. 76-81.

Arazi, A. (1997). Su'luk. In Brill Encyclopedia of Islam Volume IX SAN - SZE. C.E. Bosworth, E. van Donzel, W. P. Heinrichs and G. Lecomte (Eds) (pp. 863-868). Brill.

Arberry, A. J. (2018). Routledge Revivals: The Seven Odes (1957): The First Chapter in Arabic Literature. New York: Routledge.

Armstrong, K. (2007). Islam: A Short History. New York: Modern Library.

Bashīr, S. (1997). Arabs and others in early Islam (Vol. 8). Princeton: Darwin Press.

Borg, G. (1998). Sa'alik. In Encyclopedia of Arabic Literature Vol. 2 (pp. 670-671). New York: Routledge.

Furani, K. (2012). Silencing the Sea: Secular Rhythms in Palestinian Poetry. Stanford: Stanford University Press.

Haydar, A. F. (1977). The Mu'allaqa of Imru' Al-Qays: Its Structure and Meaning. Edebiyat, 2(1), 227-261.

Irwin, R. (Ed. . (2002). Night \& Horses \& the Desert: An Anthology of Classical Arabic Literature. New York: Anchor.

Jones, A. (2011). Early Arabic Poetry: Select Poems. Eastbourne: Sussex Academic Press.

Lane, E. W. (1872). An Arabic-English Lexicon: Derived Fom the Best and the Most Copious Eastern Sources: Comprising a Very Large Collection of Words and Significations Omitted in the Kámoos, with Supplements to Its Abridged and Defective Explanations... and Examples in Pros (Vol. 1, Issue 4). Williams and Norgate.

Mansour, Wisam. (2005). The Reality beyond the Hyperbolic Accentuation of Self in AlShanfarā's Poem "Lāmiyyatu'1 'Arab". Journal of Near Eastern Studies. Vol. 64. No.4. pp. 257-269.

Monroe, J. T. (2017). Oral Composition in Pre-Islamic Poetry. In Early Islamic Poetry and Poetics (pp. 1-54). New York: Routledge.

Parry, M., Lord, A. B., \& Bartók, B. (1954). Serbocroatian heroic songs. Cambridge: Harvard University Press.

Stetkevych, S. P. (1993). The Mortals Speak: Pre-Islamic Poetry and the Poetics of Ritual. New York: Cornell University Press. 